\title{
PRZEŻYCIE DOBRA, JAKIM JEST CZŁOWIEK

\author{
MIŁOSIERDZIE W WIZJI ŚW. JANA PAWŁA II \\ I PAPIEŻA FRANCISZKA
}

Miłosierdzie nie przestaje bulwersować. Jedni uważają, że daje ono za mało, nie zmienia radykalnie sytuacji krzywdy i niesprawiedliwości, inni zaś sądzą, że narusza zdrowe poczucie sprawiedliwości. Przede wszystkim jednak miłosierdzie nie mieści się w mentalności nastawionej na sukces i bezwzględną doskonałość, wnosi coś nieprzewidywalnego, czerpie ze źródeł, które są gdzieś głęboko ukryte i dlatego niepokoją. Mamy kłopot nie tylko z konsekwentnym praktykowaniem miłosierdzia, lecz również kłopot poznawczy; nasze myślenie z trudem przyswaja tę kategorię w jej głębi i pełni, zamiast przyswojenia wolimy ją oswajać, neutralizować i banalizować. Do miłosierdzia mają dystans zarówno ludzie dalecy od chrześcijaństwa, jak i całkiem liczni chrześcijanie.

Papieże naszych czasów stawiają miłosierdzie w centrum głoszenia Ewangelii współczesnemu światu. W nauczaniu św. Jana Pawła II i papieża Franciszka miłosierdzie nie stanowi dodatku do chrześcijaństwa, lecz wyraża się w nim jego istota jako wydarzenia zbawczego, jest znakiem obecności chrześcijan w świecie naznaczonym złem i ludzkimi dramatami. Idea miłosierdzia ma w naszych czasach wielkich proroków - Jana Pawła II i Franciszka, ale nie są oni jej właścicielami, nie są też jej twórcami, obydwaj głoszą, że miłosierdzie jest najpierw przymiotem Boga, jest Jego imieniem. Poznanie miłosiernego Boga, którego głosi chrześcijaństwo, prowadzi do odkrycia zasady miłosierdzia jako klucza chrześcijańskiego humanizmu. Obydwa pontyfikaty - papieża z Krakowa i papieża z Buenos Aires - łączy niezwykły dar ukazywania humanistycznego wymiaru chrześcijaństwa. Ich zaangażowaniu w nędze i konflikty współczesności towarzyszy antropologiczna refleksja nad przeżyciem dobra, jakim jest człowiek. O sile ich przesłania stanowi spójne zrośnięcie doświadczenia, wiary i refleksji. To właśnie dzięki takiej syntezie rdzenna chrześcijańska prawda o miłosierdziu - częściowo zapomniana, częściowo wypaczona - staje się żywa. 


\section{Zobaczyć godność człowieka}

Wiadomo, jak znaczący wpływ na przemyślenia Karola Wojtyły/Jana Pawła II na temat miłosierdzia mieli krakowscy świadkowie miłosierdzia - brat Albert Chmielowski i siostra Faustyna Kowalska, beatyfikowani i kanonizowani przez Jana Pawła II. W jego życiowym i intelektualnym spojrzeniu na człowieka jest światło, iskra pochodząca z przeżyć polskiego malarza i polskiej zakonnicy. Czytelników papieskiej encykliki Dives in misericordia oraz młodzieńczego dramatu Karola Wojtyły Brat naszego Boga zdumiewa ideowa ciągłość pomiędzy obydwoma tekstami. Pisany zaraz po wojnie utwór odzwierciedla religijne i społeczne poszukiwania młodego kapłana i zawiera już dojrzałą antropologię, proponującą spojrzenie na człowieka nie z zewnątrz, lecz w świetle prawdy jego wnętrza.

Dojrzewający do swego nowego powołania Adam Chmielowski uświadamia sobie, że wobec ogromu materialnej nędzy oraz zranień psychicznych, będących udziałem ludzi społecznie wykluczonych, żebrzących o pomoc, szukających schronienia w noclegowniach, nie wystarczy jedynie instytucjonalna likwidacja biedy ani przez filantropów, ani tym bardziej przez rewolucjonistów, instrumentalizujących ludzki gniew. Wie, że człowiekowi, którego spotyka społeczne nieszczęście, „trzeba dać dojrzałość ludzką”, bo jest w nim „coś więcej niż żebrak oparty o latarnię"1. Malarz Adam dostrzega w żebraku godność człowieka i przeżywa jej degradację. Diagnozuje zło w sposób bardziej radykalny, niż czynią to filantropi i rewolucjoniści, skupieni na zewnętrznej stronie bytowania człowieka. Wie, że nędza i niesprawiedliwość uniemożliwiają ludziom wykluczonym realizację ich osobowej pełni, odbierają im nie tylko dobra materialne, lecz przede wszystkim odbierają im samych siebie. Powołanie do franciszkańskiej służby ubogim rodzi się w malarzu Adamie jako owoc moralnego i religijnego wstrząsu wobec faktów pogwałcenia obrazu Boga w człowieku.

Głębokie widzenie krzywdy domaga się całkowitego oddania, nawet za cenę odrzucenia swej już ukształtowanej tożsamości artysty: „Nie mogę miłować po połowie. Są to dla mnie dwie otchłanie, które ciągną. Nie można pozostawać ciągle w połowie drogi między jedną a drugą" ${ }^{2}$. Miłosierdzie jest najpierw wewnętrzną odpowiedzią na ból spowodowany złem w świecie zewnętrznym, przeobraża ono wnętrze artysty, który nie chce pozostawać bezdusznym obserwatorem, nie chce też zostać działaczem, którego uwadze umyka sedno sprawy: poniżenie człowieka w jego człowieczeństwie. Dążenie do podźwignięcia bliźnich związane z troską o to, aby otworzyć przed nimi drogę ku ludzkiej dojrzałości, o której mówi Adam,

1 K. Wojtyła, Brat naszego Boga, [w:] K. Wojtyła, Jan Paweł II, Poezje, dramaty, szkice. Tryptyk rzymski, Kraków 2004, s. 346-347.

2 Tamże, s. 352. 
pomaga najpierw jemu samemu dokonać radykalnego wyboru. Adam przeżywa wezwanie do pełni człowieczeństwa na drodze samozatraty wraz z uświadomieniem sobie więzi z każdym człowiekiem, porusza go materialna i społeczna nędza, ponieważ uderza ona w godność ludzką. W istocie malarz Adam, który staje się bratem Albertem, naśladuje Jezusa Chrystusa. Niedokończony obraz Ecce Homo zostaje przeniesiony z dziedziny sztuki w dziedzinę egzystencji, sfera działań artystycznych skupionych na pięknie zostaje poszerzona o wymiar dobra. Kenoza malarza odzwierciedla kenozę Chrystusa.

Miłosierdzie polega na wspólnym przeżywaniu utraconej godności, dlatego nie uwłacza ono temu, kto go doznaje. Prawdę tę formułuje św. Jan Paweł II w encyklice Dives in misericordia. „Relacja miłosierdzia opiera się na wspólnym przeżyciu tego dobra, jakim jest człowiek, na wspólnym doświadczeniu tej godności, jaka jest jemu właściwa"3 Warto myśl tę poprowadzić jeszcze o krok dalej, korzystając z oryginalnej myśli Karola Wojtyły dotyczącej wspólnoty ludzkiej. Swoją książkę Osoba $i c z y n^{4}$ wieńczy on rozważaniami na temat uczestnictwa, a w późniejszych pracach dopełnia ów zarys teorii uczestnictwa jeszcze uwagami o alienacji, rozumianej jako przeciwieństwo uczestnictwa. Prowadzone w analitycznym, pojęciowym języku rozważania wcale nie są odległe od egzystencjalnie i religijnie doniosłej kwestii miłosierdzia. Odsłaniając antropologiczny fundament praktyki miłosierdzia, pozwalają zrozumieć, że chrześcijańska postawa miłosierdzia odpowiada głęboko prawdzie o osobie ludzkiej, co więcej uwyraźnia ją i wyostrza.

Uczestniczyć znaczy działać i spełniać się jako osoba we wspólnocie osób. Działając wspólnie z innymi, tworzymy określone wspólnoty celów, wiąże nas dobro, do którego wspólnie dążymy i wspólnie je osiągamy. Zasada uczestnictwa pozwala zauważyć jednostronność zarówno indywidualistycznej koncepcji osoby, traktującej jednostkę jakby była „samotną wyspą”, jak i jednostronność totalizmu, przyznającego wyższość kolektywowi nad jednostką, nieraz aż do pogardy tym, co niepowtarzalne i jedyne w każdym człowieku. Międzyludzkie więzi rodzą się, na co zwracano uwagę już w filozofii greckiej, z ludzkiej niewystarczalności. Potrzebujemy siebie nawzajem, aby osiągnąć pełniejszy rozwój tak indywidualny, jak i społeczny. Wojtyła dodaje, że istotnym elementem dobra wspólnego jest personalistyczna wartość czynu, dzięki której realizuje się prymat osoby jako sprawcy działającego w sposób świadomy i wolny, na miarę godności osoby.

Uczestnictwa nie należy jednak ograniczać wyłącznie do zewnętrznego wymiaru relacji międzyludzkich, wiąże ono bowiem osoby jeszcze głębiej niż sięga sama sfera społeczna - przenika ich człowieczeństwo. Chodzi tutaj o uczestnictwo

3 Jan Paweł II, Dives in misericordia, 6, [w:] Encykliki Ojca Świętego Jana Pawła II, t. 1, Kraków 1996, s. 74.

4 K. Wojtyła, Osoba i czyn oraz inne studia antropologiczne, Lublin 1994. 
w człowieczeństwie innych osób. Jestem nie tylko członkiem pewnej wspólnoty, ale jesteśmy w niej wspólnie jako bliźni.

Pojęcie „bliźni” - wyjaśnia kard. Wojtyła - jest związane z człowiekiem jako takim oraz z samą wartością osoby bez względu na jakiekolwiek odniesienie do takiej czy innej wspólnoty lub społeczeństwa. Pojęcie „bliźni” uwzględnia, czyli ma wzgląd na samo tylko człowieczeństwo, którego posiadaczem jest tak samo każdy „inny” człowiek, jak i „ja” sam. Pojęcie „bliźni” stwarza więc najszerszą płaszczyznę, sięgającą dalej niż jakakolwiek „inność” - m.in. również ta, która wynika z członkostwa w różnych wspólnotach. [...] Pojęcie „bliźni” wskazuje więc na rzeczywistość najbardziej powszechną - na najbardziej też powszechną podstawę wspólnoty pomiędzy ludźmi ${ }^{5}$.

Trzeba pamiętać, że uniwersalna interpretacja pojęcia „bliźni” dokonała się w Jezusowej przypowieści o miłosiernym Samarytaninie, stanowiącej punkt zwrotny w historii religii i zarazem historii etyki. Nie można także pominąć faktu, że w tym przypadku Jezus nie odwołuje się do autorytetu Objawienia, jak czynił to wcześniej, odnosząc się do pytania o porządek przykazań. Znamienne, że nauczyciel z Nazaretu posługuje się opisem doświadczenia moralnego, będącego udziałem Samarytanina, a więc człowieka pozostającego poza kręgiem Przymierza Abrahama. Znaczy to, że we wrażliwym moralnie sercu znajduje się zdolność do zobaczenia bliźniego w każdym człowieku. Miłosierdzie rodzi się z poruszenia serca widokiem nieszczęścia ludzkiego, jest ono praktyczną konsekwencją przeżycia dobra, jakim jest sam człowiek. Obcy religijnie i etnicznie Samarytanin, najprawdopodobniej kupiec, który według współczesnych teoretyków etyki biznesu powinien najpierw pilnować swego interesu, a nie rozdawać pieniądze po drodze, potrafi w przypadkowo spotkanym człowieku rozpoznać swego brata. Bycie bliźnim wystarczy i zasadniczo jest jedyną racją, aby wyjść mu naprzeciw w potrzebie i niebezpieczeństwie. Uznanie kogoś za bliźniego jest odpowiedzią na jego godność. Troska, jaką miłosierny Samarytanin okazuje nieznanemu bliżej człowiekowi, wynika z głębokiej więzi, której nie da się sprowadzić do elementów wyłącznie zewnętrznych, niezależnie od ich wysokiej rangi, właściwej dla sfery społecznej i religijnej, więź ta jest bowiem wpisana w samą istotę człowieczeństwa.

Zwróćmy jeszcze uwagę na to, że zasada miłosierdzia w encyklice Dives in misericordia zostaje ukazana jako klucz do współczesnej kwestii społecznej. Nowoczesne społeczeństwa kształtowały się na drogach poszukiwań sprawiedliwości, co wyznaczało z jednej strony kierunki emancypacji narodowej, klasowej, rasowej czy płciowej, a z drugiej strony prowadziło do burzliwych napięć i wyłaniania się nowych obszarów niesprawiedliwości. Czy sprawiedliwość zawodzi? W ocenie

5 Tamże, s. 330-331. 
św. Jana Pawła II jest ona konieczna, ale sama nie wystarczy. Dopiero miłosierdzie jako działanie bezpośrednie w sferze międzyosobowej, wypływające z przeżycia dobra, jakim jest osoba - stanowiąca niepowtarzalną podmiotowość - koryguje i ustawia sprawiedliwość na solidnym fundamencie aksjologicznym. Ideom nie wybaczamy, natomiast wybaczamy osobom. Bez ducha wybaczenia i pojednania podziały społeczne tylko się pogłębiają, każda strona, a jest ich mnogość, jakże charakterystyczna dla społeczeństw pluralistycznych, obstaje przy swojej narracji, rzutującej na wizję sprawiedliwości. Miłosierdzie nie odsuwa pragnienia sprawiedliwości na bok, nie pomniejsza jej znaczenia w skali społecznej, chroni natomiast tkankę relacji międzyosobowych przed atrofią na płaszczyźnie nazbyt ogólnych projektów. Nie pozwala ono zgubić człowieka pośród spraw ludzkich, nie godzi się na podporządkowanie dobra osoby wymogom ładu społecznego, ekonomicznego czy politycznego. Miłosierdzie wykracza poza wszelki ład, ale bynajmniej go nie burzy, realizuje się nie w porządku struktur, lecz w porządku serca.

Ponadto Jan Paweł II zauważa możliwość wypaczenia sprawiedliwości paradoksalnie przez nią samą. Zbyt rygorystyczne realizowanie sprawiedliwości może nawet rodzić krzywdę. Warto przytoczyć tę intrygującą uwagę papieża:

Doświadczenie przeszłości i współczesności wskazuje na to, że sprawiedliwość sama nie wystarcza, że - co więcej - może doprowadzić do zaprzeczenia i zniweczenia siebie samej, jeśli nie dopuści się do kształtowania życia ludzkiego w różnych jego wymiarach owej głębszej mocy, jaka jest miłość. To przecież doświadczenie dziejowe pozwoliło między innymi, na sformułowanie twierdzenia: summum ius - summa iniuria. Twierdzenie to nie deprecjonuje sprawiedliwości, nie pomniejsza znaczenia porządku na niej budowanego, wskazuje tylko w innym aspekcie na tę samą potrzebę sięgania do głębszych jeszcze sił ducha, które warunkują porządek sprawiedliwości ${ }^{6}$.

Wspomniano już, że w zarysie swej personalistycznej filozofii społecznej Karol Wojtyła przeciwstawiał pojęcie uczestnictwa pojęciu alienacji. Przejął je oczywiście z myśli Hegla i Marksa. W totalizującej wizji niemieckich myślicieli alienacja dokonuje się w nurcie procesów historycznych, stanowiąc ich napęd, a do jej przezwyciężenia wystarczy racjonalne kierowanie tymi procesami, czy to na drodze filozofii, czy to na drodze rewolucji. Wojtyła rozwija inną koncepcję: alienacja dotyczy kondycji konkretnej osoby, uwikłanej w zastaną sytuację, która nie pozwala osiągnąć jej osobowej pełni. Droga wyzwolenia z alienacji prowadzi poprzez miłosierdzie, zakorzenione w przeżyciu dobra, jakim jest człowiek, ten oto człowiek - ecce homo - istota ludzka obdarzona godnością, narażoną na różnorodne formy degradacji,

6 Jan Paweł II, Dives in misericordia, 12. 
Na wizję miłosierdzia Jana Pawła II wpłynęło bez wątpienia jego własne doświadczenie; odczytuje on swą biografię jako pełną tajemnicy lekcję Bożego Miłosierdzia. Poświęcenie bazyliki w Łagiewnikach zakończył wymownym osobistym wspomnieniem, tętniącym poruszającą, z natury poetycką, siłą konkretu:

Przychodziłem tu zwłaszcza w czasie okupacji, gdy pracowałem w pobliskim Solvayu. Do dzisiaj pamiętam tę drogę, która prowadziła z Borku Fałęckiego na Dębniki, którą odbywałem codziennie, przychodząc w drewnianych butach. Takie się wówczas nosiło. Jak można sobie było wyobrazić, że ten człowiek w drewniakach kiedyś będzie konsekrował bazylikę Bożego Miłosierdzia .

Stulecie, w którym wypadło mu żyć, określa jako wiek wyjątkowych doświadczeń, przez jakie przechodziła ludzkość, poddawana wielokrotnym falom brutalnej przemocy. Zastanawiając się nad zamachem na swoje życie, wyraża przekonanie, że był on "jedną z ostatnich konwulsji XX-wiecznych ideologii przemocy".

U źródeł ideologii przemocy znajduje się odrzucenie Boga Stwórcy i Odkupiciela człowieka. Spojrzenie na dramat XX wieku poprzez przypowieść o Synu Marnotrawnym i Dobrym Ojcu wyrasta z wiary, że obecności zła towarzyszą zawsze łaska i miłosierdzie. Skala Bożego Miłosierdzia nakazuje pamięć o ogromie zła, jakiego doświadczyli ludzie ubiegłego wieku. „Zło XX wieku nie było złem w jakimś małym «sklepikowym» wydaniu. To było zło na wielką skalę, zło, które przyoblekło się w kształt państwowy, aby dokonać zgubnego dzieła, zło, które przybrało kształt systemu"9 . W sytuacji tak granicznej, że określono ją wręcz „katastrofą antropologiczną,, wiara w Boże Miłosierdzie jawi się jako jedyne wyjście, jedyne, ponieważ nie jest ono oparte na „logice tego świata”, lecz wyraża się w nim „logika Bożego działania”, pokonującego zło dobrem, odrzucenie wiernością. Teologia wcielonego, ukrzyżowanego, miłosiernego Boga wnosi światło do antropologii i ocala ją przed definitywną samolikwidacją.

\section{Kościół jako szpital polowy}

Papież Franciszek pojawił się jako „papież niespodzianka”. Tak go określił na samym początku pontyfikatu Andrea Riccardi, autor jednego z pierwszych studiów poświęconych papieżowi z krańca ziemi. Niespodzianka Franciszka wiąże

7 Łagiewniki, 17 sierpnia 2002. Bogaty w miłosierdzie Bóg. Jan Paweł II w Ojczyźnie 16-19 sierpnia 2002, Kraków 2002, s. 79.

8 Jan Paweł II, Pamięć i tożsamość, Kraków 2005, s. 170.

9 Tamże, s. 171. 
się nie tylko z jego biografią, w końcu każdy papież ma wyjątkową i niepowtarzalną biografię; według Riccardiego papież Franciszek zaskoczył Kościół pogrążony w kryzysie - zajęty samym sobą, przerażony rozmiarami sekularyzacji - profetyzmem ewangelii miłosierdzia. „Przesłanie Franciszka jawi się temu, kto go słucha, jako coś, co pochodzi z serca i co mówi do serca, jednocząc i integrując. Stworzyła się nowa komunikacja z ludźmi. Jest to rzeczywistość, która wszystkim otwiera oczy" ${ }^{10}$. Styl komunikacji Franciszka, nacechowany bezpośredniością, kolokwialnością, jest pochodną jego głębokiej znajomości współczesnego człowieka, w którego sercu nie wygasło pragnienie bliskości i czułości Boga. Stylu Franciszka nie można sprowadzać do jakiejś arbitralnie przyjętej taktyki, tkwi on w samym centrum nowości, jaką jest chrześcijaństwo, będące bardziej wydarzeniem zbawczym niż doktryną i dyscypliną. Kardynał Walter Kasper zauważa, że „miłosierdzie oznacza zobaczyć sytuację i żyć w bliskości, dostrzegając drugiego. Na tym polega nawrócenie: wyjść z autoreferencyjności i otworzyć się na relację z innymi. Miłosierdzie zmienia życie" ${ }^{11}$.

Podejmując ideę miłosierdzia jako ideę odnowy Kościoła, Franciszek ukazuje żywą i płodną warstwę dziedzictwa św. Jana Pawła II. Wraz z Franciszkiem idea ta zakorzenia się w świadomości Kościoła wobec nowych wyzwań na progu III Tysiąclecia, ku któremu tak wytrwale kierował swe spojrzenie papież Polak. Ukazując ideę miłosierdzia jako klucz do tożsamości chrześcijańskiej i misji chrześcijan w świecie, Franciszek zaczyna w punkcie, do którego Jan Paweł II doprowadził Kościół i ludzkość. Jest to na wskroś twórcza kontynuacja, uwzględniająca w tradycji moc kształtowania współczesności, mierzenia się w sposób adekwatny, na miarę nowości i piękna Ewangelii, z aktualnymi dramatami. Idea miłosierdzia chroni Kościół przed izolacją i unikiem w stosunku do sprawy człowieka zranionego przez zbójców na drodze.

Rolę Kościoła we współczesnym świecie Franciszek porównuje do szpitala polowego, który musi nieść pierwszą pomoc. Miłosierdziem, zgodnie z tą metaforą, ratuje się życie i leczy się najcięższe rany. Eklezjologiczna terminologia papieża Franciszka nie ma charakteru dogmatycznego. Z jednej strony wychodzi ona poza język biblijny, a z drugiej strony bardzo przypomina właściwości języka biblijnego, osadzonego w realiach życia, tyle że u Franciszka są to realia współczesne. Franciszek nie uprawia teologii spekulatywnej, myśli całkowicie po duszpastersku: stawia diagnozę i szuka właściwej terapii, zdolnej nieść światło wiary i radość Ewangelii na peryferia egzystencjalne. Bez zrozumienia prymatu opcji pastoral-

10 A. Riccardi, La sorpresa di papa Francesco. Crisi e futuro della Chiesa, Milano 2013, s. 31 (tłum. fragmentu A. M. Wierzbicki).

11 W. Kasper, Świadek miłosierdzia. Moja podróż z Franciszkiem, z kard. Walterem Kasperem rozmawia Raffaele Luise, tłum. M. T. Szwemin, Warszawa 2016, s. 95. 
nej w nauczaniu Franciszka łatwo wypaczyć, a nawet strywializować, niektóre jego wypowiedzi, wypływające $z$ autentycznego ducha miłosierdzia. Nie ma ono $\mathrm{w}$ istocie nic wspólnego z pobłażliwością, dobrotliwością, a tym bardziej z relatywizmem, który nie koi ran, lecz je powoduje. Franciszek przyznaje, że do postawy miłosierdzia, polegającego na pochylaniu się nad ludzką kruchością, dojrzewał poprzez wszystkie etapy swej kapłańskiej posługi. „Do tego by przyznać centralne miejsce miłosierdziu - które stanowi dla mnie najważniejsze przesłanie Jezusa - dojrzewałem stopniowo podczas mojego życia kapłańskiego. Było to skutkiem mojego doświadczenia spowiednika, wielu pozytywnych i pięknych historii, które poznałem" ${ }^{\prime 2}$.

Kościół jako szpital polowy nie zapomina o Bogu, przeciwnie - pragnie ukazać bliskość Boga, którego nie sposób zamknąć w granicach konfesyjnych czy w przestrzeni sakralnej. Wymownym symbolem głoszenia Ewangelii miłosierdzia jest celebrowanie liturgii Wieczerzy Pańskiej w rzymskim więzieniu, połączone z obmyciem nóg więźniom i więźniarkom, katolikom i muzułmanom. Bezwarunkowa otwartość na uchodźców, wrażliwość na bezdomnych wyrasta z przeżycia prawdy o Bogu ukrytym w każdym człowieku. Humanistyczne chrześcijaństwo Franciszka kładzie bardziej akcent na ortopraksję niż ortodoksję, co nie znaczy, że prawdy wiary przestają mieć znaczenie. Profetyzm Franciszka polega w gruncie rzeczy na tym, że głosi on wiarę w Chrystusa świadectwem czynów. Obchody Roku Miłosierdzia należy rozumieć jako dopełnienie Roku Wiary, pamiętając o słowach św. Jakuba Apostoła, że wiara bez uczynków jest martwa.

Nie sposób przynajmniej nie zasygnalizować, że Franciszkowa linia miłosierdzia w duszpasterstwie spotyka się z niezrozumieniem, a nawet z kontestacją. Dochodzi ona do głosu po adhortacji Amoris laetitia. W posynodalnej adhortacji nie ma zerwania $\mathrm{z}$ dotychczasowym nauczaniem Kościoła na temat małżeństwa i rodziny ani odejścia od dyscypliny sakramentalnej, dopuszczającej do Eucharystii wiernych w stanie łaski uświęcającej. Logika miłosierdzia, jaką konsekwentnie rozwija papież Franciszek, skłania do takiego stylu duszpasterstwa osób znajdujących się w sytuacjach nieregularnych, aby na drodze towarzyszenia i wnikliwego rozeznania móc stwierdzić, czy istotnie znajdują się oni w sytuacji grzechu ciężkiego. Miłosierdzie nakazuje pozostawianie raczej drzwi otwartych aniżeli pochopnego ich zamykania, a nawet, jak mówi Franciszek, podjęcia „ryzyka pobrudzenia się ulicznym błotem"13. Jest to duszpasterstwo, które odrzuca język potępienia, mentalność „,kontrolerów łaski”, świadome, że obok małżeństw, którym udało się wypełnić chrześcijański ideał, znajdują się coraz liczniejsi wierni prze-

12 Franciszek, Miłosierdzie to imię Boga, rozmowa z Andreą Torniellim, tłum. J. Ganobis, Kraków 2016, s. 23-24.

13 Franciszek, Amoris laetitia. O miłości w rodzinie, 308, Częstochowa 2016, s. 252. 
żywający dramat rozpadu małżeństwa. Miłosierdzie wymaga patrzenia w serca ludzi, otwierania i podnoszenia za sprawą głębszego rozeznania:

Wierząc, że wszystko jest białe lub czarne, czasami zamykamy drogę łaski i wzrostu oraz zniechęcamy do wysiłków na rzecz świętości, które oddają chwałę Bogu. Przypomnijmy, że mały krok pośród wielkich ludzkich ograniczeń, może bardziej podobać się Bogu niż poprawne na zewnątrz życie człowieka spędzającego dni bez stawiania czoła poważnym trudnościom ${ }^{14}$.

Czy w słowach tych nie słychać silnego echa praktycznej mądrości Adama z dramatu Karola Wojtyły Brat naszego Boga: „trzeba dać im dojrzałość ludzką” ${ }^{15}$ ? Logika miłosierdzia nie traci z punktu widzenia ani ideału, ani realnej - często zdegradowanej - kondycji człowieka, dopuszcza paradoks, że mały krok na drodze do dojrzałości i naprawy swego życia jest krokiem wielkim.

W rozmowach z Andreą Torniellim Franciszek stwierdza, że zawsze trzeba szukać choćby najmniejszej szczeliny, poprzez którą może dotrzeć do człowieka miłosierdzie Boże. Legalistyczne podejście spod znaku sprawiedliwości rozmija się zazwyczaj z troską o prawdziwą wewnętrzną przemianę grzesznika. Franciszek wyjaśnia:

Kiedy doświadcza się objęć miłosierdzia, kiedy pozwala się na bycie przytulonym, kiedy jesteśmy poruszeni, wówczas życie może się odmienić, ponieważ próbujemy odpowiedzieć na ów ogromny i nieoczekiwany dar, który w ludzkich oczach może wydawać się wręcz „niesłuszny”, tak jest obfity ${ }^{16}$.

Boskie miłosierdzie uczy, że człowiek w oczach swego Stwórcy i Odkupiciela nigdy nie traci wartości otrzymanej w akcie stworzenia oraz potwierdzonej i odnowionej przez dzieło odkupienia.

Chrześcijaństwo weryfikuje się przez to, co wnosi w dzieje człowieka, poprzez to, jak głęboko wyraża się w nim miłość do konkretnego człowieka, która ożywia nauczanie i działalność Jezusa Chrystusa. Kultura, którą tworzy chrześcijaństwo, jest w swej istocie kulturą miłosierdzia. Również na polu refleksji o kulturze Franciszek odnawia język, ukazuje prymat wymiaru ludzkiego, podkreśla nadrzędność porządku serca wobec kalkulacji i polegania wyłącznie na instytucjach.

\footnotetext{
Tamże, 305.

K. Wojtyła, Brat naszego Boga, dz. cyt., s. 346.

Tamże, s. 59-60.
} 
Jesteśmy powołani, aby rozwijać kulturę miłosierdzia w oparciu o odkrycie spotkania z innymi: kulturę, w której nikt nie patrzy na innych obojętnie lub odwraca wzrok, gdy widzi cierpienie innych. Uczynki miłosierdzia sq „rękodziełem”: żaden z nich nie jest taki sam jak inny; nasze ręce mogą je kształtować na tysiąc sposobów i chociaż inspiruje je jeden Bóg i jest jedna „materia”, z której są wykonane, czyli samo miłosierdzie, to każdy nabywa odrębną formę ${ }^{17}$.

Spróbujmy dopowiedzieć: niepowtarzalność każdego z czynów miłosierdzia rodzi się z niepowtarzalności zarówno każdorazowego przeżycia dobra, jakim jest człowiek, jak i z niepowtarzalności samego dobra każdego człowieka. Kultura miłosierdzia - w przeciwieństwie do utopii, których tak wiele w cywilizacji technokratycznej - nie ulega mirażom całkowitego wyeliminowania zła, lecz próbuje przeciwstawiać się mu w konkretnych sytuacjach, które są sytuacjami spotkania człowieka z człowiekiem, spotkania zakorzenionego w jeszcze głębszym spotkaniu człowieka z Bogiem.

Franciszek lubi metafory i gesty, pozwalają one wyrazić się jego sercu. Nie ma potrzeby przeciwstawiania języka serca językowi dogmatów i prawa, trzeba jednak pamiętać, że tylko piękno porywa i umożliwia komunikację serc szukających sensu. W gestach Franciszka odsłania się piękno Ewangelii. Z jednej strony papież jest strażnikiem Tradycji, a z drugiej strony jego Piotrowy autorytet wymaga, aby Ewangelię wcielał na nowo, ponieważ „dzis’” nie jest już „wczoraj”, a nowość Ewangelii nigdy nie przemija.

Jednym z pierwszych gestów Franciszka była rezygnacja z mieszkania w watykańskim Pałacu Apostolskim i zamieszkanie w skromnym apartamencie w Domu św. Marty. Odebrano to jako gest na rzecz Kościoła ubogiego, dostrzegano w nim także pragnienie biskupa Rzymu bycia bliżej swych współpracowników, spotykania ich na co dzień, niejako spontanicznie, choćby na korytarzu, w windzie i jadalni. Przekonuje mnie sugestia Massima Franco, że wybór Domu św. Marty ma związek z papieską wizją Kościoła jako szpitala polowego ${ }^{18}$. Dom św. Marty powstał w czasie pontyfikatu Jana Pawła II, po przebudowie dawnego papieskiego lazaretu, w którym leczono w XVI wieku Rzymian zarażonych cholerą. A w czasach II wojny światowej Pius XII w tym samym budynku stworzył azyl dla Żydów oraz włoskich oponentów faszyzmu. Tradycja tego domu wiele mówi i czyni go doprawdy domem miłosierdzia.

17 Franciszek, List apostolski Misericordia et misera, 20, Kraków2016, s. 57.

18 Por. M. Franco, Il Vaticano secondo Francesco. Da Buenos Aires a Santa Marta: come Bergoglio sta cambiando la Chiesa e conquistando i fedeli di tutto il mondo, Milano 2014. 


\section{Abstract \\ Living through Good which is Man. Mercy in the Vision of St. John Paul II and Pope Francis}

In essay is pointed out the continuity and creative development of views and practice of Mercy by St. John Paul II and Pope Francis. Already in an early Karol Wojtyła's literary work The brother of our God, where the protagonist is brother Albert (Adam Chmielowski) strikes very deep and mature vision of the idea of mercy and charity. This idea is the crucial message of the pontificate of John Paul II, present in his Encyclical Letter Dives in misericordia and in his comments on the contemporary history and his own autobiography. Also his personalistic philosophy presented in his philosophical study The acting person sheds light on the basic claim according to which mercy consists in the lived experience of good which is man himself.

The approach of Francis to the contemporary moral and social challenges is prevalentely pastoral and it derives from his rich experience. The idea of mercy is linked to the vision of Church as the camp hospital. The dogmatic language is replaced by care of the true good of men and women, in creating the proper condition for becoming more human and more conscious of the concretness of the human dignity. Francis constantly preaches the attitude of tenderness in the interpersonal relations as being radiation of the merciful God. 